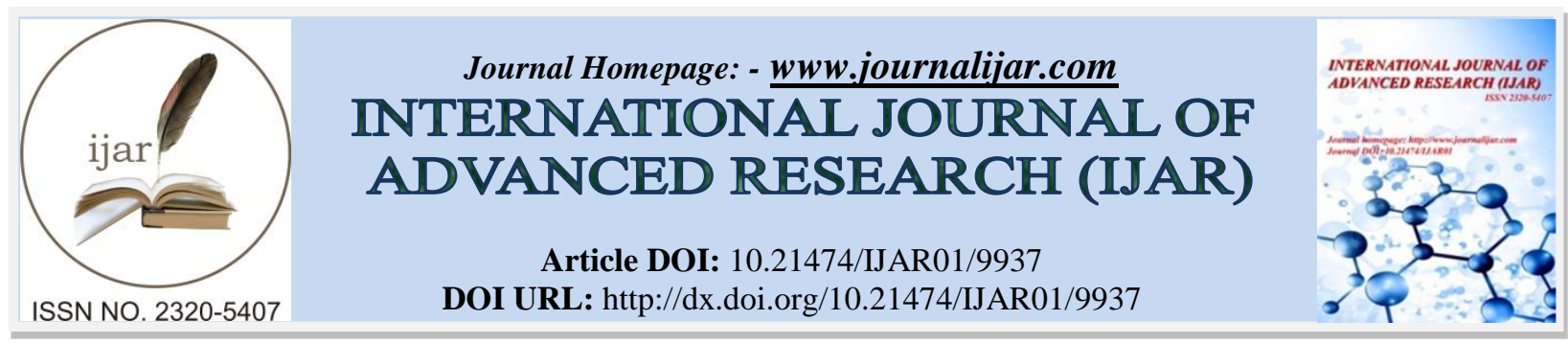

RESEARCH ARTICLE

\title{
COMPARISON OF RED CELL DISTRIBUTION WIDTH (RDW) AND APACHE II SCORE AS PROGNOSTIC MARKER AMONG PATIENTS OF SEPSIS AND SEPTIC SHOCK IN A TERTIARY CARE INSTITUTE, SOUTHERN RAJASTHAN.
}

\section{Dr. Murugesh Manjunatha ${ }^{1}$, Dr Hemant Mahur ${ }^{2}$, Dr. D. P. Singh ${ }^{3}$, Dr. Darshan R. S $^{4}$, Dr. Shaitan Singh Jat ${ }^{4}$ and Dr. Rajath Raos.}

1. Resident, Dept of Medicine, Maharana Bhupal Associate group of hospitals and RNT Medical College, Udaipur, Rajasthan[India].

2. Professor, Dept of Medicine, Maharana Bhupal Associate group of hospitals and RNT Medical College, Udaipur, Rajasthan[India].

3. Senior Professor, Dept of Medicine, Maharana Bhupal Associate group of hospitals and RNT Medical College, Udaipur, Rajasthan[India].

4. Resident, Dept of Medicine, Maharana Bhupal Associate group of hospitals and RNT Medical College, Udaipur, Rajasthan[India].

5. Resident, Dept of Preventive and Social Medicine, Maharana Bhupal Associate group of hospitals and RNT Medical College, Udaipur, Rajasthan[India].

\section{Manuscript Info}

Manuscript History

Received: 18 August 2019

Final Accepted: 20 September 2019

Published: October 2019

Key words:-

APACHE 2 score, RDW, Sepsis.

\section{Abstract}

Despite advancements, severe Sepsis and septic shock are increasing and contributing significantly to mortality. Acute Physiology and Chronic Health Evaluation (APACHE) II scoring is used as an index of illness severity and for outcome prediction. However, calculating it is cumbersome. Recent studies reported that Red Cell Distribution Width (RDW) is associated with prognosis in Critical Illness and as a part of Complete Blood Count, it is tested in all patients of sepsis. Hence, this study is being done to see correlation between RDW and sepsis.

Materials and methods: A hospital-based prospective observational study done for a year on 50 patients admitted with sepsis and septic shock in the intensive care units of RNT Medical College \& MBGH, Udaipur after taking consent. The necessary details were taken in Proforma and data was analyzed in MS excel and the results were interpreted \& significance was attributed to $\mathrm{P}<0.05$

Results: Out of 50 patients- 21 were non-survivors, $15(71.43 \%)$ were males \& most of the patients in the age group of 41-60 years (47.62\%) in non-survivors. Amongst survivors, $19(65.52 \%)$ were males \& most of the patients in the age group of 61-80 years (37.93\%) Mean APACHE II score among non-survivors was $30.43 \pm 6.14$ and $16.14 \pm 6.50$ among survivors. Mean RDW among non-survivors was $16.09 \pm 2.24$ and among survivors was $14.45 \pm 1.45$.

Conclusion: There was a statistically significant positive correlation between APACHE II \& RDW among survivors and non-survivors. In developing countries like India, RDW levels measured on admission can be used as a prognostic marker in severe sepsis and septic shock. 
Copy Right, IJAR, 2019,. All rights reserved.

\section{Introduction:-}

Severe Sepsis and septic shock are increasing in incidence and contributing significantly to mortality. ${ }^{1,2}$ The incidence rate of sepsis has increased at a rate of $8.7 \%$ per year. ${ }^{1}$ Despite advancements, the mortality rate is still between $17.9 \%$ and $28.6 \% .^{3}$ The prediction of outcome for patients with sepsis may facilitate more aggressive interventions. The degree of severity is, most often, quantified by the Acute Physiology and Chronic Health Evaluation (APACHE) II score, which can predict the severity and outcome of multiple organ failure. ${ }^{4}$ It is probably the best-known and most widely used score. It includes 34 individual variables, a chronic health evaluation, and the two combined to produce the severity score. The APACHE II score is the modification of the original APACHE scoring proposed by Knaus WA, et $\mathrm{al}^{5}$.However, calculating APACHE II Score is cumbersome. ${ }^{6}$ It would be advantageous to identify a biomarker that would be associated with the degree of severity in patients with sepsis.

The red cell distribution width (RDW) is the coefficient of variation in red blood cell (RBC) volume and is representation of the RBC size heterogeneity of an individual patient. ${ }^{7}$ RDW is elevated by increased red cell destruction, nutritional deficiencies and blood transfusions ${ }^{8}$. Recent studies have reported that Red Cell Distribution Width (RDW) is associated with prognosis in Critical Illness, Heart failure, Acute Myocardial Infarction, Pulmonary Embolism, Pneumonia and Cardiac Arrest. ${ }^{9-14}$

The positive gain from the above study may be of economic benefit to the patient and as well as to the system in terms of expenditure and time. The ultimate benefit could be in terms of improved outcomes because of earlier and more accurate assessment of the septic threat, leading to earlier prediction of deterioration, quicker response, more effective and timely therapeutic strategies. RDW as a part of Complete Blood Count (CBC) is tested in all patients of sepsis. Hence, this study is being done to see the correlation between RDW and sepsis.

\section{Aims \& Objectives:-}

1. To study the role of Red cell distribution width(RDW) as a prognostic marker among survivors and nonsurvivors in patients of severe sepsis and septic shock

2. To compare APACHE II and RDW among survivors and non-survivors in patients of sepsis and septic shock.

\section{Methodology:-}

This was a hospital based prospective observational study done for a period of 1 year (August 2017- July 2018) in RNT Medical college and attached MB Government Hospital, Udaipur, Rajasthan over 50 patients who fulfilled selection criteria.

\section{Inclusion criteria:}

Patients admitted to Intensive Care Units (ICU) who met the criteria of Severe Sepsis and Septic Shock \& age $>18$ years

\section{Exclusion criteria:}

1. Bleeding $>10 \%$ blood volume.

2. Blood product Transfusion in the previous week of admission.

3. Recent Chemotherapy.

4. Previous History of diseases primarily affecting Red Blood Cells.

5. Use of drugs known to change Morphology and Theology of Red Blood Cells.

6. Pregnancy.

\section{Data collection:}

After taking the informed consent, 50 patients of sepsis \& septic shock were assessed, vital parameters, age, past history and GCS were recorded and blood samples for Complete Blood Count including RDW and ABG were sent. Other tests such as liver function tests, renal function tests, serum electrolytes, electrocardiography, chest X-ray and USG abdomen were done. The following data and investigations were entered in the clinical Proforma. Study subjects were divided into two groups of non-survivors and survivors. Clinical parameters, Laboratory investigations, APACHE II score and RDW were compared among the two groups.

Corresponding Author: Hemant Mahur

Address:- Professor, Dept of Medicine, Maharana Bhupal Associate group of hospitals and RNT Medical

College, Udaipur, Rajasthan[India]. 


\section{Data Analysis:}

All the data was compiled tabulated and analysed for variation for mean and correlation by SPSS 20.0 Statistical package program. The quantitative data of the groups was compared using ANOVA (Analysis of Variance) and the qualitative data was compared using Chi-square test. $\mathrm{P}$ value $<0.05$ was considered significant. The data obtained was coded and entered in Microsoft Excel spreadsheet. The categorical data was expressed as rates, ratios and percentages and comparison was done.

\section{Ethical clearance:}

This study was approved from the Ethical and Research Committee. RNT Medical College and attached group of hospitals, Udaipur (Rajasthan).

INFORMED CONSENT: The patients fulfilling selection criteria were informed in detail about the risks and benefits of the procedure and a written informed consent was obtained before enrolment.

\section{Results:-}

A total number of 50 patients of sepsis and septic shock were included in the study out of which 21 were nonsurvivors and 29 were survivors. Their vitals, laboratory investigations along with RDW and APACHE II were calculated and compared between the two groups.

Most of the patients were in the age group of 41-60 years in non-survivors (47.62\%) and 61-80 years in survivors (37.93\%). Among non-survivors 15(71.43\%) were males and 6(28.57\%) were females, while in survivors $19(65.52 \%)$ were males and $10(24.48 \%)$ were females. Fever was the most common presenting symptom in nonsurvivors (100\%) compared to $75.86 \%$ survivors who came with fever. In our study Diabetes mellitus was the most common co morbidity among non-survivors $(57.14 \%)$ and survivors $(24.13 \%)$. Dialysis Dependency was also common among non-survivors $(23.80 \%)$.

Baseline variables showed that Mean arterial pressure was lower among non-survivors $(59.52 \pm 5.21)$ as compared to survivors $(92.86 \pm 12.82)$ with a p value of 0.0392 (Table 1).

Table 1:-showing Baseline variables compared with Outcome

\begin{tabular}{|l|l|l|l|l|}
\hline \multirow{2}{*}{ Baseline Variables } & \multicolumn{2}{|l|}{ Outcome } & \multirow{2}{*}{ Mean \pm SD } & \multirow{2}{*}{ P value } \\
\cline { 2 - 3 } & Non-survivors & Survivors & & \\
\hline Age (years) & $54.09 \pm 16.50$ & $50.00 \pm 16.68$ & $51.72 \pm 16.77$ & 0.001 \\
\hline Temperature $\left({ }^{\circ} \mathrm{F}\right)$ & $101.77 \pm 1.28$ & $100.47 \pm 1.16$ & $101.02 \pm 1.37$ & 0.992 \\
\hline $\begin{array}{l}\text { Respiratory } \\
\text { breaths/min) }\end{array}$ & $28.90 \pm 4.97$ & $22.70 \pm 3.97$ & $25.26 \pm 5.35$ & 0.819 \\
\hline Heart rate (beats/min) & $119.57 \pm 8.07$ & $103.38 \pm 9.86$ & $110.18 \pm 12.14$ & 0.920 \\
\hline $\mathrm{MAP}^{(m m H g)}$ & $59.52 \pm 5.21$ & $92.86 \pm 12.82$ & $78.86 \pm 19.43$ & 0.039 \\
\hline $\mathrm{SpO}_{2}(\%)$ & $91.09 \pm 7.18$ & $94.34 \pm 2.96$ & $92.98 \pm 5.41$ & 0.877 \\
\hline
\end{tabular}

Laboratory findings: Mean Total leucocyte count (TLC)was $26134.76 \pm 6967.05$ cells cu/mm in non-survivors and $14572.41 \pm 9143.17$ cells cu/mm in survivors with $\mathrm{p}$ value 0.001 . Mean $\mathrm{PaO} 2$ was $157.98 \pm 116.33 \mathrm{mmHg}$ among nonsurvivors and $382.39 \pm 112.77 \mathrm{mmHg}$ among survivors with $\mathrm{p}$ value $=0.001$. Mean $\mathrm{pH}$ was $7.32 \pm 0.16$ in nonsurvivors and $7.35 \pm 0.11$ in survivors.

To calculate APACHE 2 score, following parameters were taken. Mean serum creatinine was $3.97 \pm 3.11 \mathrm{mg} / \mathrm{dl}$ in non-survivors and $3.28 \pm 3.16 \mathrm{mg} / \mathrm{dl}$ in survivors. Mean serum sodium among non-survivors was $129.30 \pm 9.49 \mathrm{mEq} / \mathrm{dl}$ and $133.55 \pm 5.47 \mathrm{mEq} / \mathrm{dl}$ among survivors. Mean potassium levels among non-survivors were $3.58 \pm 1.08 \mathrm{mEq} / \mathrm{dl}$ and among survivors were $3.72 \pm 0.62 \mathrm{mEq} / \mathrm{dl} \&$ Mean GCS was $9.14 \pm 3.46$ in non-survivors and $14.55 \pm 1.33$ in survivors with $\mathrm{p}$ value of 0.0232 .

Mean APACHE II score among non-survivors $30.43 \pm 6.14$ and $16.14 \pm 6.50$ among survivors with a $\mathrm{p}$ value of 0.0011.(Table 2)

Table 2:-showing APACHE II Scores among Non-Survivors \& Survivors of Sepsis

\begin{tabular}{|l|l|l|l|}
\hline APACHE II score & Non-survivors $(\mathbf{n}=\mathbf{2 1})$ & Survivors $(\mathbf{n}=\mathbf{2 9})$ & P value \\
\hline$<15$ & 0 & 12 & 0.0011 \\
\hline
\end{tabular}




\begin{tabular}{|l|l|l|l|}
\hline $15-24$ & 4 & 14 & \\
\cline { 1 - 2 } & 17 & 3 & \\
\hline Mean \pm SD & $30.43 \pm 6.14$ & $16.14 \pm 6.50$ & \\
\hline
\end{tabular}

Mean RDW among non-survivors was $16.09 \pm 2.24 \%$ and among survivors was $14.45 \pm 1.45 \%$ with a $\mathrm{p}$ value of 0.0225.(Table 3)

Table 3:- showing comparison of RDW with the Outcome

\begin{tabular}{|l|l|l|l|}
\hline RDW (\%) & Non-survivors $(\mathbf{n = 2 1})$ & Survivors $(\mathbf{n = 2 9})$ & P value \\
\hline$\leq 14.5$ & 1 & 18 & \multirow{3}{*}{0.0225} \\
\cline { 1 - 2 } $14.6-17.3$ & 18 & 9 & \\
\cline { 1 - 2 } & 2 & 2 & \\
\hline Mean \pm SD & $16.09 \pm 2.24$ & $14.45 \pm 1.45$ & \\
\hline
\end{tabular}

The APACHE II and RDW were significantly higher in non-survivors than survivors with significant $\mathrm{p}$ value (Figure 1)

Figure 1: - showing Comparison of APACHE II Score \& Serum RDW according to Outcome of sepsis

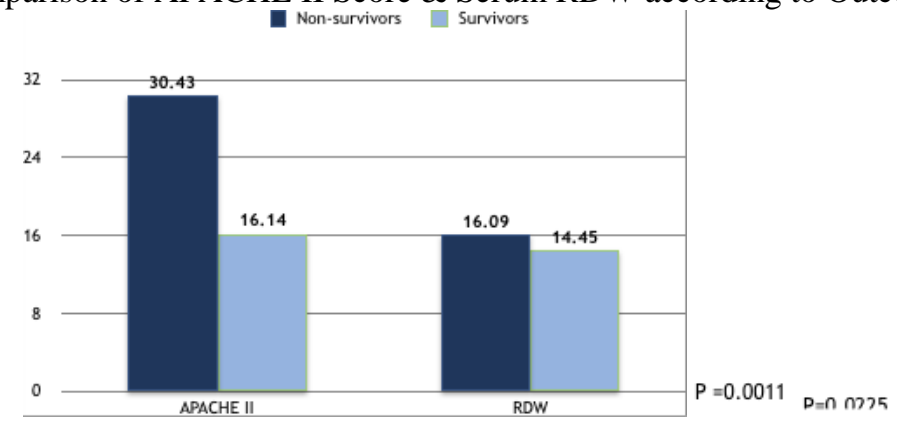

\section{Discussions:-}

Sepsis and septic shock are one of the leading causes of death worldwide. Early detection and prompt administration of antibiotics has been shown to reduce mortality and morbidity in patients with sepsis. Hence, various markers have been evaluated for earlier diagnosis of sepsis. There are many other markers of sepsis which are being evaluated for its diagnosis among which RDW is emerging as a promising marker.

In our study, the mean age group was $51.72 \pm 16.72$ years. But the study done by $\mathbf{J o} \mathbf{~ Y H}$ et al. ${ }^{15}$, the mean age was $70.0 \pm 13.4$ years.

Males were predominant in our study $(68 \%)$ is in accordance with study done by Zhongzheng hang et $\mathbf{a l}^{\mathbf{1 6}}(65.4 \%)$.

Diabetes Mellitus (57.14\%) and Dialysis dependency (23.80\%) were the two most common co-morbidities in our study.

According to Henry E. Wang et $\mathbf{a l}^{\mathbf{1 7}}$ the most common co-morbidities were chronic lung disease and peripheral artery disease. As India has the maximum growing population of diabetes and its complications in the world, in our study the most common co-morbidity was diabetes and dialysis dependency.

In our study the mean APACHE II score among non-survivors was $30.43 \pm 6.14$ and was $16.14 \pm 6.50$ among survivors and was statistically significant with a p value of 0.0011 .

This is in accordance with Boonen et al ${ }^{18}$ who studied 100 patients with abdominal sepsis. According to their study APACHE II score in non-survivors $(19.5 \pm 5.9)$ was significantly higher than survivors $(11.7 \pm 6.4)$.

A study done by NA Mahmood et $\mathbf{a} \mathbf{l}^{\mathbf{1 9}}$ was also associated with increased mortality in patients of sepsis with $\mathrm{n}$ APACHE II score of $\geq 15$ as compared to the patients with a score $<15$. 
Mean RDW among non-survivors was $16.09 \pm 2.24$ and $14.45 \pm 1.45$ among survivors which was statistically significant ( $p$ value $=0.0225$ ). This is in accordance with $\mathbf{~ J o ~} \mathbf{Y H}$ et $\mathbf{a l}^{\mathbf{1 5}}$ where Red cell distribution width was significantly higher in non-survivors than in survivors, and the corresponding mortality of patients with an RDW of $14 \%$ or less, $14.1 \%$ to $15.7 \%$, and $15.8 \%$ or greater was $13.1 \%, 30.1 \%$, and $44.9 \%$, respectively.

Edal Braun et $\mathbf{a l}^{\mathbf{2 0}}$ studied patients of community acquired pneumonia and found out that higher RDW (>16) at the time of admission was an independent risk factor for mortality and severe morbidity and was unrelated with hemoglobin, WBC count and age.

\section{Conclusion: -}

There was a statistically significant correlation between APACHE II among survivors and non-survivors. RDW was statistically significant among survivors and non-survivors. There was a significant positive correlation between RDW and APACHE II score.

In developing countries like India, RDW levels measured on admission can be used as a prognostic marker in severe sepsis and septic shock.

\section{Limitations: -}

As our study included only 50 patients of sepsis and septic shock, a study with a greater number of patients is required to assess the utility and efficiency of RDW as a prognostic marker in sepsis and septic shock.

\section{References: -}

1. Martin GS, Mannino DM,Eaton S,Moss M. The epidemiology of sepsis in the United States from 1979 through 2000. New England Journal of Medicine 2003 Apr 17;348(16):1546-54

2. Kumar G, Kumar N, Taneja A, Kaleekal T, Tarima S, McGinley E, et al. Nationwide trends of severe sepsis in the 21st century(2000-2007). Chest 2011 Nov;140(5):1223-31.

3. Angus DC, Linde - Zwirble WT, Lidickee J, Clermont G, Carrillo J, Pinsky MR. Epidemiology of severe sepsis in the United States : Analysis of the incidence, outcome and associated costs of the care. Crit Care Med 2001 Jul;29(7):1303-1310.

4. Qiao Q, Lu G, Li M, Shen Y, Xu D.Prediction of outcome in critically ill elderly patients using APACHE II and SOFA scores. J Int Med Res. 2012;40(3):1114-21.

5. Knaus WA, Draper EA, Wagner DP, Zimmerman JE. APACHE II: a severity of disease classification system. Crit Care Med. 1985 Oct;13(10):818-29.

6. Del Prete M, Castiglia D, Meli M, Perri S, Nicita A, Dalla Torre A, Moraldi A. Prognostic value of C reactive protein in acute pancreatitis Chir Ital. $2001 \mathrm{Jan}-\mathrm{Feb} ; 53(1): 33-38$.

7. Evans TC, Jehle D.The red blood cell distribution width. J Emerg Med. 1991;9 Suppl 1:71-74

8. Fukuta H, Ohte N, Mukai S, Saeki T, Asada K, Wakami K, Kimura G.Elevated plasma levels of B-type natriuretic Peptide but not C-reactive protein are associated with higher red cell distribution width in patients with coronary artery disease. Int Heart J. 2009 May;50(3):301-12.

9. Felker GM, Allen LA, Pocock SJ, Shaw LK, McMurray JJ, Pfeffer MA, Swedberg K, Wang D, Yusuf S, Michelson EL, Granger CB; CHARM InvestigatorsRed cell distribution width as a novel prognostic marker in heart failure: data from the CHARM Program and the Duke Databank. J Am Coll Cardiol. 2007 Jul 3;50(1):407.

10. Dabbah S, Hammerman H, Markiewicz W, Aronson D.Relation between red cell distribution width and clinical outcomes after acute myocardial infarction. Am J Cardiol. 2010 Feb 1;105(3):312-7.

11. Zorlu A, Bektasoglu G, Guven FM, Dogan OT, Gucuk E, Ege MR, Altay H, Cinar Z, Tandogan I, Yilmaz MB. Usefulness of admission red cell distribution width as a predictor of early mortality in patients with acute pulmonary embolism. Am J Cardiol. 2012 Jan 1;109(1):128-34.

12. Braun E, Domany E, Kenig Y, Mazor Y, Makhoul BF, Azzam ZS.Elevated red cell distribution width predicts poor outcome in young patients with community acquired pneumonia.Crit Care. 2011 Aug 11;15(4):R194.

13. Bazick, Chang D, Karthik Mahadevappa, Fiona K. Gibbons, Kenneth B. Christopher. Red Cell Distribution Width and all cause mortality in critically ill patients .Crit Care Med. 2011 Aug; 39(8): 1913-1921.

14. Kim J, Kim K, Lee JH, Jo YH, Rhee JE, Kim TY, Kang KW, Kim YJ, Hwang SS, Jang HY. Red blood cell distribution width as an independent predictor of all-cause mortality in out of hospital cardiac arrest. 2012 Oct;83(10):1248-52. 
15. Jo YH1, Kim K, Lee JH, Kang C, Kim T, Park HM, Kang KW, Kim J, Rhee JE.Red cell distribution width is a prognostic factor in severe sepsis and septic shock.Am J Emerg Med. 2013 Mar;31(3):545-8.

16. Zhongheng Zhang, Xiao Xu, Hongying Ni, and Hongsheng Deng. Red cell distribution width is associated with hospital mortality in unselected critically ill patients. J Thorac Dis. 2013 Dec; 5(6): 730-736.

17. Henry E. Wang, Nathan I. Shapiro, Russell Griffin, Monika M. Safford, Suzanne Judd, George Howard.Chronic Medical Conditions and Risk of Sepsis.PLoS One. 2012; 7(10): e48307.

18. John M. A. Bohnen, Robert A. Mustard, Susan E. Oxholm, B. Diana Schouten. APACHE II Score and Abdominal Sepsis. Archives of Surgery, 123(2), 225.

19. Mahmood NA, Mathew J, Kang B, DeBari VA, Khan MA. Broadening of the red blood cell distribution width is associated with increased severity of illness in patients with sepsis.Int J Crit Illn Inj Sci. 2014 OctDec;4(4):278-82.

20. Braun, Eyal \& Kheir, Jad \& Mashiach, Tania \& Naffaa, Mohammad \& Azzam, Zaher. (2014). Is elevated Red cell distribution width a prognostic predictor in adult patients with community acquired Pneumonia? BMC infectious diseases. 14. 129. 10.1186/1471-2334-14-129. 